\title{
Working with Young People at University of Porto
}

\author{
http://dx.doi.org/10.3991/ijep.v2i1.1893 \\ J. C. Marques and M. T. Restivo \\ Universidade do Porto, Porto, Portugal
}

\begin{abstract}
This work describes several initiatives of the University of Porto in Portugal and of its Faculty of Engineering, whose common goal is to attract young people to higher education in general, and to science and technology in particular. The U.Porto Annual Exhibition is briefly mentioned and Junior University is described in some detail. The Engineering Open Days and the EMPE Portal for secondary school students are also presented.
\end{abstract}

Index Terms-EMPE Portal, Engineering Open Days, Junior University, U.Porto Annual Exhibition.

\section{INTRODUCTION}

Many countries are actively seeking to attract more youngsters to a professional career in the fields of science and technology. Portugal is no exception to this trend. But in complement to this particular emphasis in science and technology, a national effort is also being made to bring more young people to higher education (HE) in general.

Portugal has reached a level of achievement in HE in line with that of other OECD countries, with about 35\% of 20-year-olds enrolled in HE. The number of students in public $\mathrm{HE}$ institutions has risen from 277,000 to 288,000 , new $1^{\text {st }}$ year students from 84,000 to 115,000 and graduates from 51,000 to 66,000 per year, in the period 2005-2009 [1]. Nevertheless a mere $16.5 \%$ of the active population (24.8\% in the age group 25-34 years) has HE qualifications (well below the 28\% OECD average).

Among other policies this has led to the signing in January 2010 of an important 4-year agreement, a "Contract of Confidence for HE", between the Minister of Science, Technology and HE and all 35 public HE institutions [1], involving an increase of their budget by 100 million Euros per year, against the accomplishment of the strategic goal of an additional 100,000 graduates until 2014.

After providing some background data about the city of Porto and its University (U.Porto) this work first describes two very successful and original initiatives launched by U.Porto, targeted to youngsters aged from 11 to 17 and their families: "Mostra da U.Porto" (U.Porto Annual Exhibition) and "Universidade Júnior" (Junior University).

Then the focus moves to two activities promoted within the Faculty of Engineering aimed at motivating teenagers to pursue their studies in one of the ten engineering areas on offer: the Engineering Open Days and the "Portal EMPE" (Exploration of Multidisciplinary Problems in Engineering Portal).

\section{Porto AND ITS UnIVERSITY}

According to the official figures for 2011 [2] the resident population in Portugal slightly exceeds 10.5 million inhabitants. Porto, with over 235,000 inhabitants (1.28 million in the metropolitan area), is the second largest city in the country.

With roots dating back to 1762 U.Porto is currently the largest of the fifteen public universities in Portugal, with over 31,000 students (8,900 postgraduates), 2,470 teachers and researchers and 1,700 technical and administrative staff, in its 14 faculties, one business school and 60 research units spread across the city in 3 campuses [3]. Around 2,600 international students attend U.Porto each year.

The university offers over 700 training programmes per year, from bachelor, master and doctoral degrees to continuing professional education. U.Porto has 1,945 fulltime equivalent lecturers and professors (76\% holding a doctorate). It produces over $20 \%$ of the Portuguese papers indexed each year in the ISI Web of Science, being the largest education and research institution in the country.

\section{U.PORTO ANNUAL EXHIBITION}

"Mostra da U.Porto", the annual Science, Education and Innovation Event launched in 2003, is an opportunity for the academia to exhibit the diversity of its areas in a large venue, using scientific knowledge issues for attracting the general public. During a Thursday to Sunday four-day period in March numerous secondary schools, their teachers and students, visit the show and interact directly with University collaborators (Fig. 1).

Many U.Porto teachers and researchers are present, as well as recent graduates and final year students who are particularly gifted in engaging the youngsters while providing feedback and attending to their questions.

This event is also a favourite with families, U.Porto alumni and the public at large. From 6,500 in 2003 the number of visitors has risen above 15,000 in 2010, with

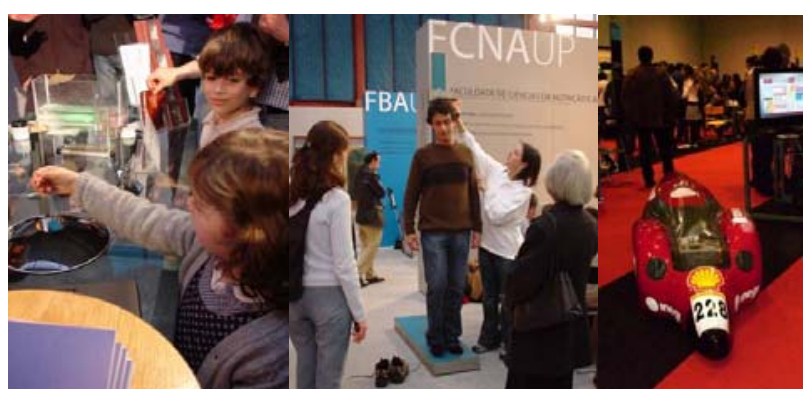

Figure 1. Activities and exhibits at "Mostra da U.Porto" 
the number of visiting schools expanding from 21 to 92. In 2009 a conference cycle entitled "Science: what else?" further complemented this event.

\section{UNIVERSIDADE JÚNIOR}

After a process of internal discussion and diagnosis on how to motivate secondary school youngsters for continuing their studies at higher education level [4], U.Porto organized in July 2005 the first edition of Universidade Júnior (UJr), a pioneering project aimed at students in the 11 to 17 age group [5] that has rapidly become a huge success.

UJr programmes have several formats according to students' ages [6]. The first part of UJr happens during 4 weeks in July with Summer Experiences (for 11-12 years old), Summer Workshops (for 13-14 years old), Summer Projects (for 15-17 years old) and Language Schools (for 11 to 17 years old).

They run Monday to Friday, 09:00 to 18:00, with one week duration (two in the case of language schools). The students have their meals at the canteens like their university colleagues. Each group has at most 14 elements with two junior tutors who are recent graduates or final year students, under the coordination of one member of the academic staff. A sample of the Summer Experience and Summer Workshop programs offered in July 2011 is shown in Tables I and II.

In the Summer Projects each student is allocated a personal project for development during the week. They are expected to take home the final outcome. The topics available at FEUP in July 2011 included namely: Make a short movie; Discover Mechatronics; The universe of Civil Engineering; Musical instruments of polymeric and composite materials; The car under the magnifying glass; The small great world of nanotechnology; Biomedical image processing and analysis; Recreational and educational robotics; Use the Earth and preserve it; Let's try Chemical Engineering.

In 2011 UJr had Language Schools of German, French, Spanish, English, Japanese, Greek, Latin and Russian.

The second part of UJr comprises one-week schools in September, where top students of the 10th and 11th grades are introduced to more advanced activities and research environments in the fields of Life and Health Sciences, Chemistry, Mathematics and Physics, supervised by junior researchers or $\mathrm{PhD}$ students.

The activities of UJr take place in many labs and research centres of all 14 Faculties of U.Porto and at the School of Music and Performing Arts of the Polytechnic Institute of Porto. A hands on, "learning by doing" approach is generally adopted, with fieldwork and thematic visits also included. Fig. 2 displays examples from three different areas.

The students come from as far as the Algarve, over 500 $\mathrm{km}$ away in Southern Portugal. A lodging program is provided for such cases (covering 375 students per week, 250 of them girls). Over 40 City Councils offer transportation and scholarships. The participants have been consistently above 4,000 (5,189 in 2011) [7].

Visits to the UJr portal (http://universidadejunior.up.pt) in the period September 2010-July 2011 came from 56 countries all over the world, totalling more than 100,000.
This novel approach, while relatively new in Europe, is the object of an international network of organizing institutions, the European Children's University Network (EUCU.NET), with 127 programs already active in 23 European countries. UJr is one of its founding members.

UJr has been successfully pursuing several goals, ranging from the promotion of knowledge in the fields of science, technology, art, humanities and sport, to vocational orientation and enticement for HE by providing a foretaste of life at the University.

Data collected from the seven editions of UJr show that it has generated a positive effect on student recruitment. In 2011 almost $15 \%$ of the $41301^{\text {st }}$ year students enrolled at U.Porto had attended one or more editions of UJr [8].

Table III shows the evolution of the $1^{\text {st }}$ phase of admissions of $1^{\text {st }}$ year students to U.Porto for the period 20022009 [9]. In 2009, and for the very first time in Portugal, all the places on offer at U.Porto were taken in this phase. It is fair to admit that to some extent this remarkable achievement may be due to the impact of UJr, whose effect started to be visible two years after its first edition in 2005.

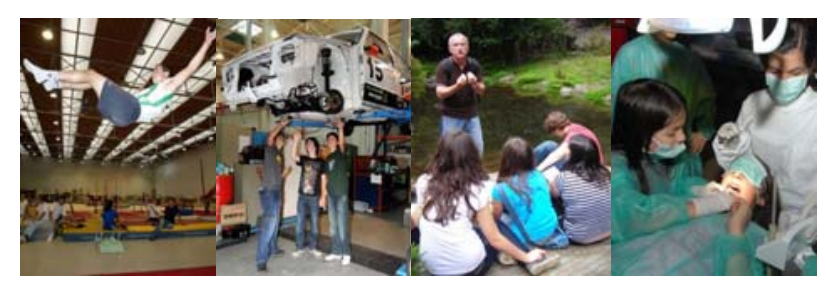

Figure 2. UJr activities in sport, mechanical engineering, biology and dental medicine

TABLE I.

SUMMER EXPERIENCES SAMPLE WEEK PROGRAM (ONE OF FIVE)

\begin{tabular}{|l|l|l|}
\hline $\begin{array}{l}\text { Summer } \\
\text { Experience }\end{array}$ & Venue & Topic \\
\hline Mon. & Sports Faculty & Sports \\
\hline Tue. & Fine Arts Faculty & Paint yourself \\
\hline Wed. & Science Faculty & Secret messages on plant leaves \\
\hline Thu. & Dental Medicine Fac. & Healthy teeth \\
\hline Fri. & Science Faculty & Let's know an urban lake \\
\hline
\end{tabular}

TABLE II.

SUMMER WORKSHOPS SAMPLE WEEK PROGRAM (ONE OF SIX)

\begin{tabular}{|l|l|l|}
\hline $\begin{array}{l}\text { Summer } \\
\text { Workshop }\end{array}$ & Venue & Topic \\
\hline Mon & $\begin{array}{l}\text { Psychology \& Educ. } \\
\text { Sciences Faculty }\end{array}$ & Let's go on-line \\
\hline Tue & Fine Arts Fac. & Sound and its wonders \\
\hline Wed & Science Fac. & Discover fractals \\
\hline Thu & Science Fac. & Chemistry of new materials \\
\hline Fri & Humanities Faculty & Be a star \\
\hline
\end{tabular}

TABLE III.

STATISTICS OF THE $1^{\text {ST }}$ PHASE OF APPLICATION TO U.PORTO FOR $1^{\text {ST }}$ YEAR STUDENTS

\begin{tabular}{|l|l|l|l|l|l|l|l|l|}
\hline Year & 2002 & 2003 & 2004 & 2005 & 2006 & 2007 & 2008 & 2009 \\
\hline Places (P) & 3984 & 3768 & 3870 & 3933 & 3938 & 3968 & 4025 & 4050 \\
\hline Admitted (A) & 3642 & 3447 & 3623 & 3618 & 3689 & 3947 & 4010 & 4052 \\
\hline A/P (\%) & 91.4 & 91.5 & 93.6 & 92.0 & 93.7 & 99.5 & 99.6 & 100.0 \\
\hline Applications & 19271 & 16368 & 17169 & 18405 & 18333 & 24242 & 25041 & 24904 \\
\hline
\end{tabular}




\section{ENGINEERING OPEN DAYS}

The Faculty of Engineering of University of Porto (FEUP) has been offering annually since 2001 a 3-day program of activities for disseminating its engineering areas among students and teachers from the 9th to the 12th grade. During these Open Days more than 3000 visitors are welcome at FEUP labs and services by staff and junior researchers.

The combined effect of the Open Days and the UJr activities organized at FEUP may be considered very positive in terms of student recruitment, as shown by Table IV that lists places, admissions and applications for the period 2002-2009 [9]. The figures of Table $\mathrm{V}$ show an increase in the proportion of girl candidates and girl admissions to FEUP, but also that they are becoming more competitive in this process.

TABLE IV.

STATISTICS OF THE $1^{\text {ST }}$ PHASE OF APPLICATION TO FEUP FOR $1^{\text {ST }}$ YEAR STUDENTS

\begin{tabular}{|l|l|l|l|l|l|l|l|l|}
\hline Year & 2002 & 2003 & 2004 & 2005 & 2006 & 2007 & 2008 & 2009 \\
\hline Places (P) & 745 & 745 & 770 & 770 & 795 & 810 & 830 & 840 \\
\hline Admitted (A) & 712 & 673 & 752 & 746 & 723 & 811 & 830 & 840 \\
\hline A/P (\%) & 95.6 & 90.3 & 97.7 & 96.9 & 90.9 & 100.1 & 100.0 & 100.0 \\
\hline Applications (Ap) & 3068 & 2198 & 3222 & 3079 & 2858 & 5250 & 5832 & 5166 \\
\hline Ap/P & 4.1 & 3.0 & 4.2 & 4.0 & 3.6 & 6.5 & 7.0 & 6.2 \\
\hline
\end{tabular}

TABLE V.

STATISTICS OF FEMALE PERFORMANCE IN THE $1^{\text {ST }}$ PHASE OF APPLICATION OF $1^{\text {ST }}$ YEAR STUDENTS TO FEUP

\begin{tabular}{|l|l|l|l|}
\hline Year & 2007 & 2008 & 2009 \\
\hline \% Female Admissions & 26.0 & 29.5 & 31.7 \\
\hline \% Female Candidates & 29.8 & 32.6 & 32.6 \\
\hline \% F. Adm./ \% F.. Candidates & 0.87 & 0.90 & 0.97 \\
\hline
\end{tabular}

\section{THE EMPE PORTAL}

From April 2003 to April 2005 FEUP financed a Project entitled Exploration of Multidisciplinary Problems in Engineering (EMPE) [10] whose main objective consisted in promoting the involvement of teachers, researchers and students from several Departments of FEUP in the exploration of practical problems integrating specialized know-how from various scientific areas. One of the outcomes of this Project is the EMPE Portal (http://empe.fe.up.pt), an educational portal aimed at high school students with the purpose of stimulating the curiosity and the interest of potential future FEUP students for multidisciplinary engineering problems in which physics and mathematics can be seen in action [11].

The Portal uses Web2.0 tools for increased interactivity and to respond adequately to how young people today communicate, socialize, collaborate and construct their knowledge. Each user has its own profile and network of friends within the Portal. The contents are dynamic and may be created by the users. The user is integrated in a community where he participates and contributes. The Portal has invested in creating a social network to link a community of people (with varying age, culture and experience) sharing a common interest in scientific and engineering topics, in an informal learning environment. The Portal has chat, post and personal blog creation facilities.

\section{FINAL CONSIDERATIONS}

In Portugal $2 / 3$ of the students choose their future profession between the 7th and the 9th grades. In a study conducted by IEEE/University of Central Florida, 50\% of practicing engineers attribute their choice of profession to the direct encouragement gained by the involvement in science programs. According to official Portuguese sources, in 2003 there was a reduction in the demand for HE courses of $13.5 \%$ in Science and of $8.7 \%$ in Technology. Initiatives like those described in this work are an invaluable, well targeted contribution to reverse this trend and the results are starting to look promising.

\section{ACKNOWLEDGMENT}

The contribution of Professor José Ferreira Gomes, the "father" of Ujr, is gratefully acknowledged. Dr. Paulo Gusmão, the current head of the Ujr team, has provided most valuable information.

\section{REFERENCES}

[1] http://www.portugal.gov.pt/pt/GC18/Documentos/MCTES/Contra to_Confianca_EnsSup_Universidades.pdf.

[2] Instituto Nacional de Estatística, Statistics Portugal (http://www.ine.pt).

[3] http://sigarra.up.pt/up uk/web base.gera pagina?P pagina=12222 $\underline{5}$.

[4] E. Carrapatoso, M. T. Restivo, J. C. Marques, A. Ferreira, R. Mota Cardoso, J. Ferreira Gomes, "Motivar os jovens para as áreas da Ciência e da Tecnologia - Reflexões na Universidade do Porto". Proc. GCETE'2005, Global Congress on Engineering and Technology Education, 2005, pp. 384-387, C.R. Brito et al. (eds.), São Paulo, Brazil.

[5] J. Ferreira Gomes, J. "Universidade Júnior, a project to motivate school pupils". Proc. ICECE 2007, International Conference on Engineering and Computer Education, 2007, pp.199-203, C.R. Brito et al. (eds.), Santos, Brazil.

[6] http://universidadejunior.up.pt/

[7] Silva, V. "Universidade Júnior '11", Reitoria da U.Porto, Porto, Portugal.

[8] V. Silva, P. Gusmão, F. Mesquita, "From the Junior University to the Real University", SiS Catalyst \& EUCU.NET Joint Conference, November 2011, Ankara, Turkey.

[9] http://sigarra.up.pt/up/conteudos_geral.conteudos_ver?pct_pag_id $=122350 \& p c t \_p a r a m e t r o s=p \_p a g i n a=122350 \& p c t \_d i s c i p l i n a=\& p$ ct grupo $=886 \# 886$

[10] J. C. Marques, M. T. Restivo, “Interdisciplinarity at FEUP”. Proc. 34th SEFI Annual Conference, 2006, P. Andersson et al. (eds.), Uppsala, Sweden.

[11] H. Guimarães, J. Villate, M. T. Restivo, J. C. Marques, E. Carrapatoso, M. F. Chouzal,."A Web 2.0 aplicada a um portal educacional". Proc. CISTI 2009, 4th Iberian Conference on Information Systems and Technologies, 2009, pp.473-476, A. Rocha et al. (eds.), Porto, Portugal.

\section{AUTHORS}

J. C. Marques is with CEC, Faculdade de Engenharia da Universidade do Porto, Porto, Portugal (e-mail: jmarques@fe.up.pt).

M. T. Restivo is with IDMEC-Pólo FEUP, Faculdade de Engenharia da Universidade do Porto, Porto, Portugal (e-mail: trestivo@fe.up.pt).

Received 5 December 2011. Published as resubmitted by the authors 17 January 2012. 